\title{
Cytological Effects of Leaf Extract of Artemisia vulgaris L. on Meristematic Cells of Allium cepa $\mathrm{L}$.
}

\author{
P.D. Rai ${ }^{{ }^{*}}$, N. Paudel $^{2 * *}$ and S.R. Shakya ${ }^{1}$ \\ ${ }^{I}$ Cental Department of Botany, T.U., Kathmandu, Nepal \\ ${ }^{2}$ Department of Botany, P.G. Campus, T.U., Biratnagar, Nepal \\ E-mail:*deep_prakash@hotmail.com,**niroj_jirauna@yahoo.com
}

\begin{abstract}
Artemisia vulgaris L., a perennial aromatic shrub with bitter taste, is considered as a medicinal plant and water extract of it consists of active components like psilostachyin A, psilostachy C, Exiguaflavanone A, Mackiain, fernenol with both anti-bacterial and medicinal value. It has been used to perserve crops and stored grains both in liquid and powder by farmers. The cytological effect was observed in 5, 7.5, 10 and $20 \%$ concentrations of Leaf Extract of Artemisia vulgaris (LEA) on Allium cepa L. in five different time durations. The present study showed the correlation between concentration of LEA and duration of treatment in controlled state. Higher concentrations of LEA as well as longer duration of treatment generate the inhibitory effect on the division of cells. Lower concentration of LEA showed less effect on Mitotic Index value (MI) in comparison with control value, which is attributed to delay in metabolic activities. It also showed the change in phase indices and induced chromosomal abnormalities among the phases.
\end{abstract}

Key words: Allium cepa, Artemisia vulgaris, Medicinal plants, Mitoitc Index, Phase indices.

\section{Introduction}

The pest control potential of 2400 species was documented (Griange and Ahmed, 1988) with first documented use of Nicotiana sps. in the year 1763 in France and use of Pyrethrum in trans-Caucasian region in 1800 (Metcalf et al., 1962). It has been estimated that 324 out of 2400 species found in Nepal have potential pesticide use. Medicinal and aromatic plants show allelopathic effect to another plant but plant based residues of most of agrochemicals have been reported to be genotoxic (Amer and Farah, 1974) causing changes in behavior of different phases of cell cycle which may lead up to mutagenic or carcinogenic effect.

Artemesia vulgaris $(2 \mathrm{n}=34)$ is distributed throughout Nepal at $300-2500$ $\mathrm{m}$, common along sideways and in margins of cleared forest, also in India, Srilanka, Myanmar, Thailand, Indonesia, Philippines, South China and Japan (Manandhar, 2000). It is called Fleabean, Mugwort in English and Titepati in Nepali.

The study was designed to examine the cytological effects of LEA on cell division of Allium cepa root meristems. The experiment was performed to find out antimitotic or mitodepressive effects observing lethality in dividing cells, prophase poison, retardation of chromosome movement, c-mitosis, chromosomal irregularities as well as clastogenic effects.

\section{Materials and methods}

Allium cepa roots were used as bioassay. Root meristem raised in water is treated with different concentration of LEA such as 
$5,7.5,10$ and $20 \%$ at different durations 1 , $3,6,12$ and $24 \mathrm{hrs}$. Stock solution was prepared by matured leaves of $A$. vulgaris. Root tips excised from treated and controlled materials were fixed in 1:3 acidic solution at 10:30 AM and preserved in70\% ethyl alcohol. Root tips squashes were made using $2 \%$ aceto-carmine stain. Different phases of mitosis were counted and chromosomal abnormalities were observed to calculate mitotic indices and total abnormality percentage at different phases. Mitotic Index $(\mathrm{MI})=\mathrm{TDC} / \mathrm{TC} \times 100$

Phase Index $(\mathrm{PI})=\mathrm{TC} / 100 \mathrm{x}$ TDC

Total percentage of Abnormal Cells $\mathrm{T}_{\mathrm{Abn}}=$ $\mathrm{TC}_{\mathrm{Abn}} / \mathrm{TDC} \times 100$

Where, $\mathrm{TDC}=$ total dividing cells

$\mathrm{TC}=$ total dividing and non dividing cells

The data were subjected to statistical analysis using Freidman's test to determine the effect of duration of treatment on the mitotic index value of root tip cells of $A$. cepa.

$$
\chi_{r}^{2}=\frac{12}{N K(K+1)} \sum_{j=1}^{K}(R j)^{2}-3 N(K+1)
$$

Where,

$\mathrm{N}=$ number of rows (concentration)

$\mathrm{K}=$ number of columns (time of treatment)

$\mathrm{R}_{\mathrm{j}}=$ sum of ranks in the $\mathrm{j}^{\text {th }}$ column

$\sum_{j=1}^{k}=$ Directs one to sum of the squares of

the sums of ranks over all $\mathrm{k}$ condition.

The degree of freedom (df) was determined by the reference of the Chi $\left(\chi^{2}\right)$ square distribution with $\mathrm{df}=\mathrm{k}-1$ and the significance value were matched at percentage $(\mathrm{p})<0.05$.

\section{Results}

\section{Effect in Mitotic Index}

Mitotic index (MI) of control material was 44.02 and for treated groups this ranges between 48.53 at $5 \%$ LEA and $1 \mathrm{~h}$ treatment and 8.14 at $20 \%$ LEA and $24 \mathrm{~h}$ of treatment. Very short treatment at lower concentration (5 and $7.5 \%$ of LEA at $1 \mathrm{~h}$ ) showed increase in MI above control while the long time of treatment at various concentrations (5 and $20 \%$ of LEA at $42 \mathrm{hs}$ ) showed decrease in MI. The observation indicated that MI is inversely proportional to time and concentrations (Fig. 1).

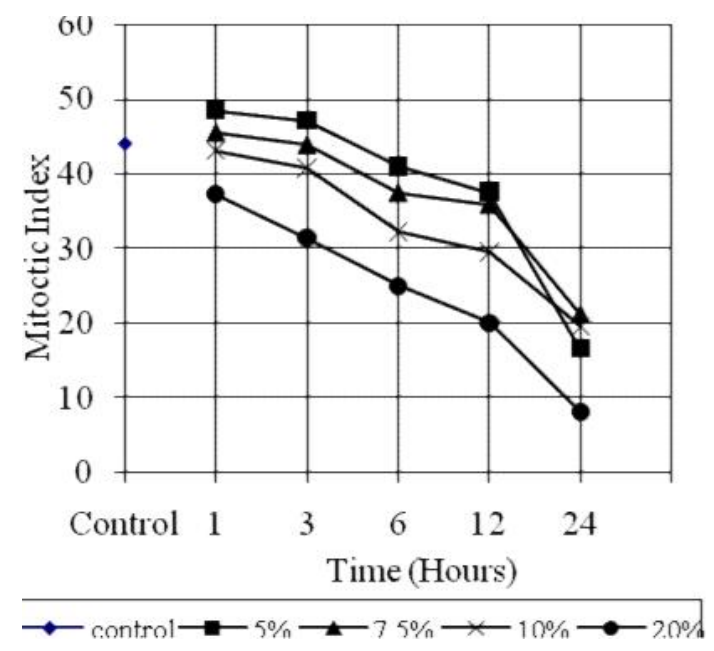

Figure 1. Graph of Mitotic Index of Allium cepa root tip cells vs treatment time with given concentration of LEA

\section{Phase Index}

Effects on Prophase Index

Prophase Index (Pro I) showed an irregular increasing trend. The Pro I value increased with increase in concentration and time of treatment. The control Pro I value was 82.65 and except the values of $10 \%$ at $3 \mathrm{~h}$ treatment, $20 \%$ at $6 \mathrm{~h}$ treatment and 5\% LEA at $12 \mathrm{~h}$ treatment which was above the control. The highest Pro I value was95.30 at 
$7.5 \%$ of LEA and $24 \mathrm{~h}$ of treatment while lowest is 80.97 at $20 \%$ of LEA and $6 \mathrm{~h}$ of treatment. This decrease was also of less significant occurrence (Fig. 2).

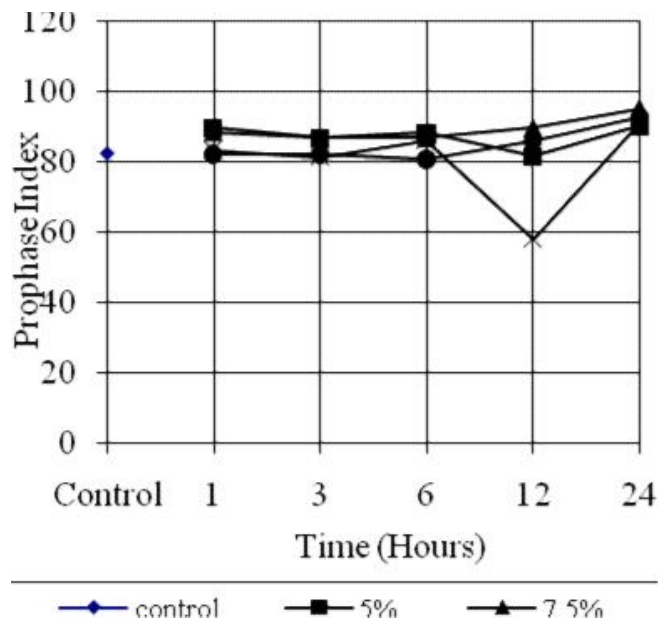

Figure 2. Graph of Prophase Index of Allium cepa root tip cells vs treatment time with given concentration of LEA

\section{Effects on Metaphase Index}

Metaphase Index (Meta I) did not show any regularity in its value and the value decreased in all concentrations and below the control value. The Meta I value for control was 7.19. The highest value 7.76 is at $20 \%$ LEA and $3 \mathrm{~h}$ treatment and exceptional value above control one, and lowest 0.78 at $7.5 \%$ LEA and $24 \mathrm{~h}$ of treatment. The graph showed a decreasing tendency, the rate increases with the increase in concentration and time (Fig. 3).

\section{Effects on Anaphase Index}

Anaphase Index (Ana I) didn't show regularity on its value. Ana I decreased in all the treated groups in comparison with the control value (5.81) except at $10 \%$ and $20 \%$ of LEA treatment for 1and $3 \mathrm{~h}$ and at $20 \%$ and $6 \mathrm{~h}$ of treatment (7.28) being the highest value. The lowest value 0.97 was observed at $20 \%$ LEA and $24 \mathrm{~h}$ of treatment (Fig. 4).
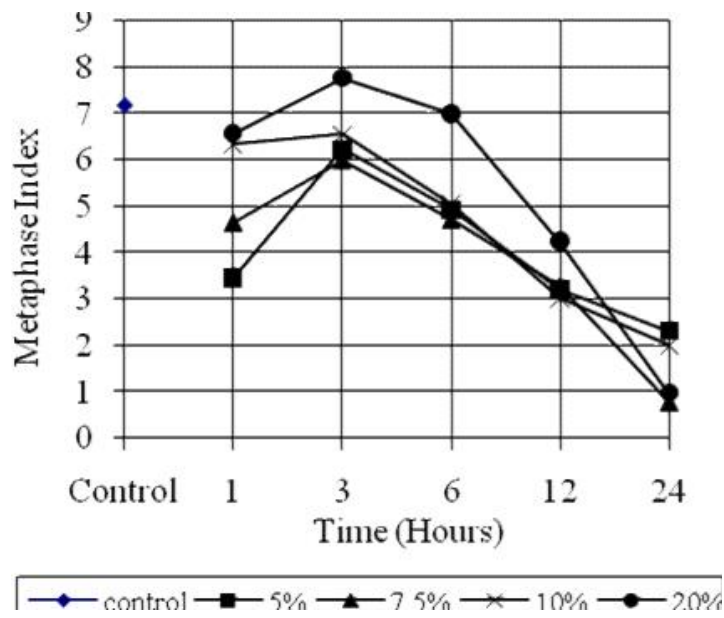

Figure 3. Graph of Metaphase Index of Allium cepa root tip cells vs treatment time with given concentration of LEA

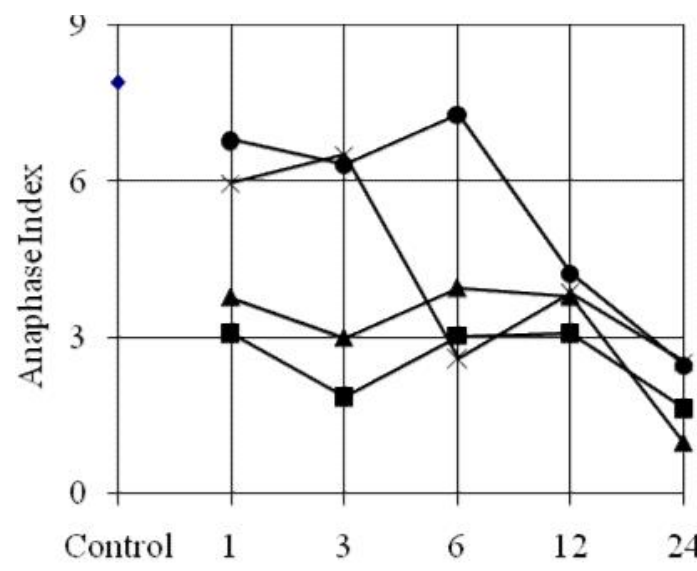

Time (Hours)

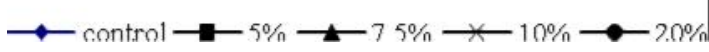


Figure 4. Graph of Anaphase Indices of Allium cepa root tip cells vs treatment time with given concentration of LEA

\section{Effects on Telophase Index}

Similarly, Telophase Index (Telo I) did not show regularity in its value neither it increase nor decreased constantly at increasing treatment period and concentration. The control Telo I value was 4.35 , the highest value was 7.97 at $10 \%$ LEA and $12 \mathrm{~h}$ treatment while the lowest 2.93 at $7.5 \%$ LEA and $24 \mathrm{~h}$ of treatment (Fig. 5).

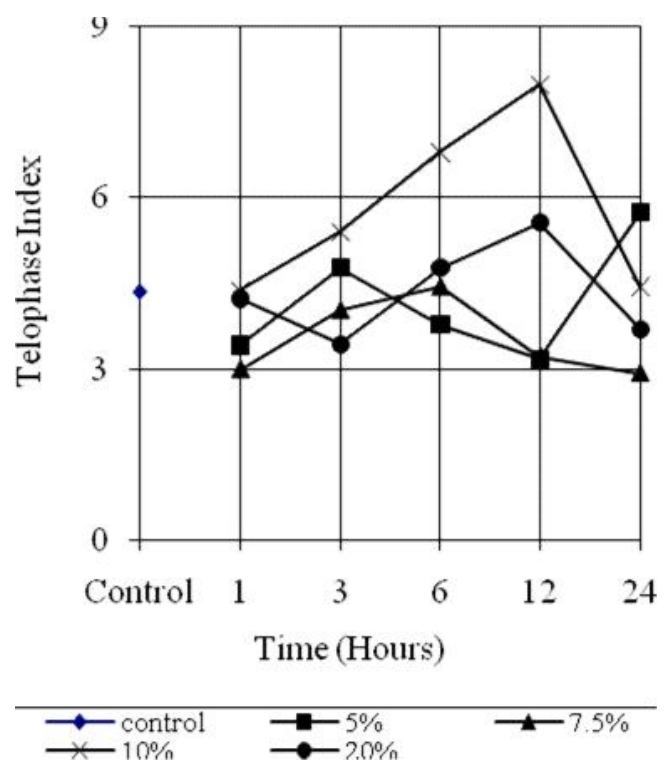

Figure 5. Graph of Telophase Indices of Allium cepa root tip cells vs treatment time with given concentration of LEA

\section{Relation between Mean Mitotic Index and Mean Phase Indices}

The mean mitotic index in all experimental groups decreased with increase in concentration of LEA and treatment time. The mean MI at control was 44.02, highest in all treatment times while lowest was
16.45 at $24 \mathrm{~h}$ of treatment. The mean Pro I showed increasing index than that of control (82.65) in all treatment times. The highest value was 92.35 at $24 \mathrm{~h}$ treatment while lowest was 84.53 at $6 \mathrm{~h}$ treatment. Mean Meta I showed in value than that of control with increase in treatment period. The highest Meta I was represented by control 7.19 and lowest was 1.52 at $24 \mathrm{~h}$ of treatment. Similar result was seen in case of Ana I where highest value 5.81 was of control and least was 1.89 at $24 \mathrm{~h}$ treatment. But Telo I value increased at all treatment times that that of control except at $1 \mathrm{~h}$ treatment. The lowest and highest Telo I value was 3.75 and 4.98 at $1 \mathrm{~h}$ and $12 \mathrm{~h}$ treatment respectively (Fig. 6).

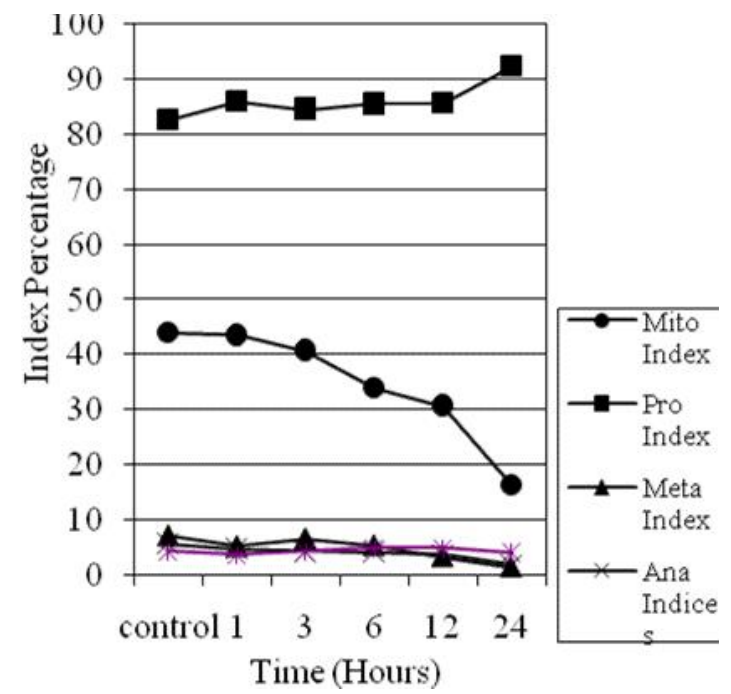

Figure 6. Graph of Mean Indices of Mitotic, Prophase, Metaphase, Anaphase and Telophase vs treatment time with mean percentage concentration of LEA.

\section{Total Percentage of Abnormal Cells}

The percentage of abnormal cells was observed mostly in all treated roots. All the 
values were above control ones but they did not show any regularity with the time of treatment and concentration. The total percentage of abnormal cells in treated roots was 6.26. Among all the treated concentration and time period, the highest abnormal value was 21.37 at $20 \%$ LEA and $6 \mathrm{~h}$ treatment and lowest was 6.75 at $7.5 \%$ LEA and $24 \mathrm{~h}$ treatment (Fig. 7).

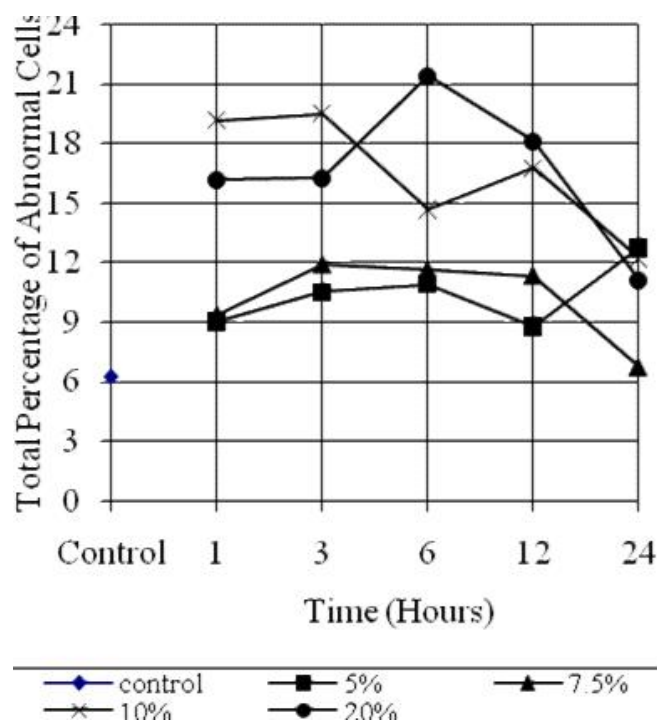

Figure 7. Graph of Total abnormal cells percentage vs treatment time with given concentration of LEA

\section{Discussion}

It is evident from the result that the mitotic index decreased considerably in different treatment. It showed abnormal chromosomal behavior during mitotic division on root tip cells of Allium cepa reflected mito-depressive property of LEA. The decrease in mitotic index may be due to the inhibitory effects of essential oil and alkaloids present in LEA. The organic compounds might affect enzyme production and function such as induction repression or feedback inhibition. Similar cytological effects have been shown by water extracts of plants like Pteridium aquilinum, Achillea frgrantissima (Shehab et al., 1978), Luffa operculata (Mederios and Takahashi, 1987) and Ricinus communis (George and Geethamma, 1990).

The Freedman's Test showed the obtained chi square $\left(\chi^{2}\right)=11$ where the tabulated value was 16 at percentage $(p)<$ 0.005 which supported effectiveness of various concentration of LEA in relation with the time treatment in cell division. In other words, it indicates that time of treatment has effect on mitotic index value.

Prophase index value didn't show any regularity and in most cases it was greater than the controlled. Prophase index value increased, in average, with increase in time and concentration. The increase in abnormality with increase in concentration supports this assumption (Shakya et al., 1999). Non-synchronized condensation of chromosome, clumping of chromosomes unequal condensation of chromatin threads and disturbed prophases were also found.

The decrease in Metaphase and Anaphase index is noted as the time of treatment and concentration increased. This may be due to prolonged prophase or the dividing cells blocked in prophase or may be due to disturbed spindle mechanism in dividing cells (Deysson, 1968). The major abnormalities found in metaphase were equatorial plate shifting, disturbed metaphase and sticky metaphases. Precocious arms and star metaphase were rarely observed. Shifting of metaphysic plate may be due to inhibition of spindle mechanism due to negative effect in DNA synthesis. Disturbed and fragmented metaphase caused by LEA is generally considered due to unfinished or disrepair of DNA. The precocious arms were due to 
abnormal behavior of centromere or spindle fiber (Adam and Farah, 1989) while star metaphase was considered as a fore step of complete disturbance of spindle (Amer, 1965).

The major types of abnormalities found in Anaphase and Telophase were nonsynchronized movement of chromosomes, fragmented chromosomes, bridge and laggards. Sticky and multipolar chromosomes were rarely observed. Nonsynchronised movement is due to unequal spindle movement (Amer and Ali, 1980). The disturbance in RNA metabolism and consequent lack of DNA, protein synthesis leads to acute fragmentation (Sharma, 1968). Bridges and laggards are observed as a result of retardness of chromosomal movements due to stickiness of chromosomal ends (Darlington and Cour, 1976). The error of spindle organization leads to multipolar spindle formation probably due to formation of more than two poles (Kumar and Sinha, 1989; EI Khodary et al., 1990). The telophase abnormality were mostly binucleated cells which is due to inhibition of cell cycle and also due to failure in cell plate formation, disorder occurred in phragmoplast formation (Olah and Hanzely, 1973). Similar result was obtained by Chauhan and Sundararaman (1990).

\section{Conclusion}

Different cytological changes produced by Artemisia vulgaris L. were investigated in root meristem of Allium cepa. Higer concentration and longer duration of treatments is toxic to cells. Different concentration of LEA showed plasmolysed cells, elongated nuclei, chromosome clumping, chromosome break and equatorial plate shifting, disoriented and non- synchronization of chromosomes, diagonal, sticky chromosomes and rare laggards, multipolar and star shaped chromosomes. LEA showed mitodepressive effect in lower concentrations. The present study revealed cytotoxic and clastogenic properties of LEA.

\section{Acknowledgements}

The authors are grateful to the Central Department of Botany, Tribhuvan University, Kirtipur, Kathmandu and Department of Botany, Post Graduate Campus, Tribhuvan University, Biratnagar for laboratory facility.

\section{References}

Adam, Z.M. and O.R. Farah 1989. Cytological effects of water extracts of medicinal plants in Egypt. Mitotic disturbances induced by water extracts of Cymbopogon proximus Halfa.(Barr) on Vicia faba. Cytologia 54: 489-492.

Amer, S.M. 1965. Cytological effects of pesticides: Mitotic effects of N-methyl-1- naphthyl carbamate "Sevin". Cytologia 30: 175-181.

Amer, S.M. and O.R. Farah 1974. Cytological effects of pesticides VI: Effects of the insecticides "Rogor" on Mitosis of Vicia faba and Gossypum barbadense. Cytologia 39: 507-514.

Amer, S.M. and E.M. Ali 1980. Cytological effects of pesticides XI: Meiotic effects of the herbicides monochloroacetic and trichloroacetic acids. Cytologia 45: 715-719.

Chauhan, L.K.S. and V. Sundaraman 1990. Effects of substituted ureas on plant cells I. Cytological effects of Isoproturon on the root meristem cells of A. cepa. Cytologia 55: 91-98.

Darlington, C.D. and L.F. Cour 1976. The handling of chromosomes. $16^{\text {th }}$ Ed., George Allen and Unwin Ltd., London.

Deysson, G. 1968. Anti- mitotic substances. Int. Rev. Cytologia 24: 99.

EI- Khodary, S., A. Habib and A. Hailem 1990. Effects of herbicide Tibumil on root mitosis of $A$. cepa. Cytologia 55: 209-215.

George, K. and S. Geethamma 1990. Effects of the leaf extract of Ricinus communis on Allium cepa. Cytologia 55: 392-394. 
P.D. Rai, N. Paudel and S.R. Shakya / Our Nature (2012) 10: 242-248

Griange, M. and A. Ahmed 1988. Handbook of plants with pest control properties. John Wiley and Sons, NY, USA.

Kumar, D. and S.P. Sinha 1989. Threshold dose of cytogenetic toxicity of Lindane, Malathion and Metacid on A. cepa root tip cells.Cytologia 54: 547-552.

Manandhar, N.P. 2000. People and plants. Timberland Press, Inc.

Mederios, M.S.G. and C.S. Takahashi 1987. Effects of Luffa operculata on Allium cepa root tips. Cytologia 52: 255-259.

Metcalf, C.L, W.P. Flint and R.L. Metcalf 1962. Destructive and useful insects. $4^{\text {th }} \mathrm{Ed}$., McGrawHill, Inc, New York.
Olah, L.V. and L. Hanzely 1973. Effects of Digitonin on cellular division. Cytologia 38: 55-72.

Shakya, P., B.S.R. Bajracharya and S.R. Shakya 1999. Cytological effect of Carpet dying effluent on somatic cells of Allium cepa. Ecoprint 6(1): 5559.

Sharma, C.B. 1968. Coumarin induced chromosome breakage in the root tips of Ephedra foliata. Boiss. var. ciliata. Cytologia 33: 94-96.

Shehab, A.S., H.A. Hakeem and Z.A. El-Kheir 1978. Cytological effects of Achillea fragrantissima extract on Allium cepa and Vicia faba. Cytologia 43: 623-629. 